University of Nebraska - Lincoln

DigitalCommons@University of Nebraska - Lincoln

Sociology Department, Faculty Publications

Sociology, Department of

$5-2020$

Changes in Religiosity Among Lesbian, Gay, and Bisexual

Emerging Adults

Brandi Woodell

Philip Schwadel

Follow this and additional works at: https://digitalcommons.unl.edu/sociologyfacpub

Part of the Family, Life Course, and Society Commons, and the Social Psychology and Interaction Commons

This Article is brought to you for free and open access by the Sociology, Department of at DigitalCommons@University of Nebraska - Lincoln. It has been accepted for inclusion in Sociology Department, Faculty Publications by an authorized administrator of DigitalCommons@University of Nebraska - Lincoln. 


\title{
Changes in Religiosity Among Lesbian, Gay, and Bisexual Emerging Adults
}

\author{
Brandi Woodell \\ Department of Sociology and Criminal Justice, Old Dominion University \\ Philip Schwadel \\ Department of Sociology, University of Nebraska-Lincoln \\ Correspondence - Brandi Woodell, Department of Sociology and Criminal Justice, Old Dominion \\ University, 6000 Batten Arts \& Letters, Norfolk, VA 23529. Email: bwoodell@odu.edu \\ ORCIDs \\ Brandi Woodell https://orcid.org/0000-0003-0888-0308 \\ Philip Schwadel https://orcid.org/0000-0002-4672-3162
}

\begin{abstract}
Highly religious Americans are relatively likely to oppose lesbian, gay, and bisexual (LGB) rights and many churches are unwelcoming to sexual minorities, which may lead LGB Americans to retreat from religion. To assess this possibility, we investigate trajectories of religious change for sexual minorities and other emerging adults. We use two longitudinal data sources (National Longitudinal Study of Adolescent to Adult Health and the National Study of Youth and Religion) to explore how sexuality predicts the likelihood of decreasing religiosity in emerging adulthood. Results show that three different operationalizations of sexual minority status - attraction, behavior, and identity-are each strongly and consistently associated with disaffiliating from religion and declines in religious service attendance. On the other hand, sexual minority status has inconsistent and relatively small associations with changes in prayer. We conclude by discussing how these results further understanding of religion, sexual identity, and the current generation of emerging adults.
\end{abstract}

Keywords: LGB, sexuality, religion, disaffiliation, attendance, prayer

Published in Journal for the Scientific Study of Religion (2020) 59:2, pp 379-396.

https://doi.org/10.1111/jssr.12653

Copyright (C) 2020 The Society for the Scientific Study of Religion. Used by permission. Submitted 7 September 2019; revised 6 February 2020; accepted 13 March 2020; published 5 May 2020. 


\section{Introduction}

Religion is strongly associated with attitudes toward lesbian, gay, and bisexual (LGB) Americans (Sherkat et al. 2011). In particular, highly religious Americans are relatively likely to oppose LGB rights (Whitehead 2018). Nonetheless, being a sexual minority and being religious are not mutually exclusive. Sexual minorities participate in various aspects of religion, including affiliating with religions, attending religious services, and individual practices such as prayer (Thumma 1991; Woodell, Kazyak, and Compton 2015). For LGB youth, being both religious and a sexual minority can induce religious stress - "the difficulty and conflict that a sexual minority youth may feel from their religion or spiritual beliefs" (Page, Lindahl, and Malik 2013:665).

Although a small but growing number of American religious groups are open and affirming (i.e., welcoming to sexual minority participants), most religious groups are seen as unfriendly to LGB Americans (Pew Research Center 2014a, 2014b). Evangelical elites in particular overwhelmingly argue that homosexuality is morally unacceptable (Thomas and Whitehead 2015). As Putnam and Campbell write, "If we know whether a person is a grace-saver or not, we also know his or her views on abortion, or homosexuality ... " (2010:152). Religious groups that are opposed to sexual minorities can create a hostile environment, thereby encouraging sexual minorities to disaffiliate from religion or to decline in their religiosity (Cotton et al. 2006).

Although churches and other religious organizations have often opposed sexual minorities, young adults today are maturing in a more accepting social climate than previous generations (Andersen and Fetner 2008). Younger generations in particular tend to have more accepting views of social issues like sexual minority civil rights than do older generations. For example, younger generations (those born after 1980) express the highest levels of support for same-sex marriage (Pew Research Center 2017). Moreover, some religious organizations have changed their stances on sexual minority civil rights, including same-sex marriage (Cadge, 0lson, and Wildeman 2008; Pew Research Center 2015). It remains to be seen how these cultural changes influence the association between sexuality and declines in religiosity, particularly among contemporary emerging adults who are maturing in a time of both greater social acceptance of minority sexualities and heightened religious and political polarization (Abramowitz and Saunders 2008; Andersen and Fetner 2008). 
In this study, we investigate how contemporary sexual minority emerging adults interact with religious institutions. Our research expands on previous research on sexuality and religion (e.g., Sherkat 2002, 2016) by examining longitudinal changes in religiosity, by assessing attraction, behavior, and sexual identity, and by focusing on emerging adults. Moreover, religion, like sexuality, is not a monolithic construct. Scholars emphasize various dimensions of religion, such as identity, affiliation, institutional practices, and individual practices (e.g., Cornwall et al. 1986; Glock 1962); and the demographic correlates of religion vary across dimensions of religiosity (e.g., Schwadel 2011). Thus, we develop separate hypotheses for how sexual attraction, behavior, and identity are associated with religious affiliation, attendance, and prayer. ${ }^{1}$ We use two longitudinal data sources, National Longitudinal Study of Adolescent to Adult Health (Add Health) and the National Study of Youth and Religion (NSYR), to explore how sexuality predicts the likelihood of decreasing religiosity in emerging adulthood. Using these two data sources allows us to build in reproducibility in our results and assure that our conclusions are not driven by the unique aspects of each sample. Results show that all three operationalizations of sexual minority status-attraction, behavior, and identity-are associated with an increased likelihood of disaffiliating from religion and with declines in religious service attendance. In addition, attraction (in the NSYR) and identity (in Add Health) are moderately associated with declines in prayer. We conclude by discussing how these results further understanding of religion, sexuality, and the current generation of emerging adults.

\section{Why we focus on contemporary emerging adults}

Emerging adulthood is a period of the life course between adolescence and adulthood when distinctive patterns of growth and development occur (Arnett 2000). This stage of the life course gives the individual the time and space necessary for identity exploration, including

1. Within the Add Health data, the correlation among our three measures of religious change are: Attendance and Prayer $r=.34$, Attendance and Disaffiliation $r=-.14$, Prayer and Disaffiliation $r=-.20$. Within the NSYR, the correlation among our three measures of religious change are: Attendance and Prayer $r=0.34$, Attendance and Disaffiliation $r=-.39$, Prayer and Disaffiliation $r=-.31$. 
the time to consider their own sexuality (Schwartz et al. 2013). By this stage of the life course, most people have recognized their sexual attraction to same- and different-sex individuals (Calzo et al. 2011; Morgan 2013). For example, 77 percent of lesbian, gay, and bisexual adults report that they first experienced a same-sex attraction before the age of 18 (Gates 2010). In addition, by emerging adulthood many who experience same-sex attraction or behavior will have adopted a sexual minority identity as contemporary emerging adults are self-identifying as sexual minorities earlier than previous generations (Calzo et al. 2011; Floyd and Bakeman 2006; Morgan 2013).

Emerging adults are also exploring their own religiosity during this stage of the life course. Emerging adulthood is a transitional time of life, when young adults generally leave their family of origin and break or weaken social ties that dominated their young lives. This change in social networks and familial and community social control leads to declines in organized religious practices in particular (Arnett and Jensen 2002). Members of this age group are thus relatively unlikely to participate in formal religious services, though the majority do not disaffiliate from religion altogether (Uecker, Regnerus, and Vaaler 2007). Emerging adults do, however, often continue to engage in more individualized religious and spiritual activities, such as prayer (Barry et al. 2010). Importantly, researchers suggest that religiosity during adolescence and emerging adulthood sets the stage for life-long religious practices and beliefs (Smith and Denton 2005; Trinitapoli and Vaisey 2009).

The current generation of emerging adults is the first to mature in a social context that is relatively accepting of sexual diversity. The number of Americans who identify as LGB, especially among young and emerging adults, is rising (Pew Research Center 2017). Acceptance of LGB individuals and support for sexual minority civil rights such as same-sex marriage, parenting rights, and nondiscrimination policies has also increased (Flores 2014; Pew Research Center 2017), particularly among religious organizations and individuals (Cadge et al. 2008; Fuist, Stoll, and Kniss 2012; Pew Research Center 2015; Schwadel and Garneau 2019). Contemporary emerging adults are thus unique in their freedom to express sexual minority identities with relatively little social repercussions (at least compared to previous generations). The focus on this stage of the life course is therefore warranted due to the prevalence of religious change during emerging adulthood and the specific social and cultural context in which contemporary emerging adults are maturing. 


\section{Religious decline among sexual minorities}

Beliefs regarding appropriate or acceptable sexuality are heavily influenced by religion (Fuist et al. 2012). Christian, particularly Protestant ideologies have shaped the sexual standard in the United States (Heath 2012). From discussions about sex education and reproductive rights to sexual minority civil rights, religion remains key to the dominant cultural narrative (Munson 2009; Stone 2016; Williams 2011). This sexual standard may lead sexual minorities to experience an identity dilemma related to holding both a sexual minority and religious identity (Page et al. 2013; Wolkomir 2006). In religions such as Judaism, Christianity, and Islam, sexual minorities must negotiate these culturally conflicting identities to avoid the negative effects of cognitive dissonance (Burge 2018; Mahaffy 1996). This often leads to either rejecting one of these conflicting identities or attempting to integrate them (Thumma 1991; Yip 1997). Those who are unable to or do not have the desire to integrate these potentially conflicting identities may choose to decline in their religious practices or disaffiliate from their religion (Barton 2012). Thus:

H1: Sexual minorities will be more likely than heterosexuals and those reporting different-sex behaviors and attractions to disaffiliate (i.e. transition from having a religious affiliation to no affiliation) in emerging adulthood.

Although most empirical research treats sexual minorities as a single social category, some research on the topic distinguishes between bisexual sexual activities, attractions, or identities and solely same-sex activities, attractions, or identities. Scheitle and Wolf (2017), for example, find that bisexual adults are more likely than heterosexuals to disaffiliate from religion while no such direct effect was observed for gay men and lesbian women. This finding aligns with similar research that suggests that religious communities often have more negative views of bisexuals than they do of lesbian and gay Americans (e.g., Sumerau, Cragun, and Mathers 2015; Toft 2012). In line with this research, we look at bisexuals as a specific group (within one of our two data sets) instead of in a combined sexual minority category to better understand their religious experiences. Thus, 
H1b: Bisexuals in particular will be more likely than heterosexuals and those reporting solely different-sex behaviors and attractions to disaffiliate (i.e. transition from having a religious affiliation to no affiliation) in emerging adulthood.

Sexual minorities may also retreat from religion by reducing their participation in religious congregations. Instead of disaffiliating from religion altogether-or in addition to disaffiliating - sexual minorities may limit their interactions in religious settings by decreasing their attendance at worship services. Such a change in religious attendance may be a way for sexual minorities to avoid facing challenges from members of religious communities, given that those who regularly attend religious services are relatively likely to hold negative attitudes about sexual minorities (Barringer, Gay, and Lynxwiler 2013). Some LGB emerging adults reject their religious identity altogether, while others may become disillusioned with the organized aspects of religion and thus relatively unlikely to attend worship services (Wedow et al. 2017). Consequently,

H2: Sexual minorities will report a greater decrease in their religious service attendance over time compared to heterosexuals and those reporting different-sex behaviors and attractions in emerging adulthood.

H2b: Bisexuals in particular will report a greater decrease in their religious service attendance over time compared to heterosexuals and those reporting solely different-sex behaviors and attractions in emerging adulthood.

In addition to these public and organizational aspects of religion, this study also addresses more individualized religious practices. Prayer is an individualized religious/spiritual activity that emerging adults, in general, tend to engage in (Barry et al. 2010). Despite some organized religions being intolerant of sexual minorities, sexual minorities may still consider prayer an important part of their religious identity (Woodell et al. 2015). Of course, the cognitive dissonance many sexual minorities experience when interacting with religious organizations can also apply to prayer. Nonetheless, as Woodell et al. (2015:869) show, some sexual minorities view prayer as a way of "doing Christianity how I want to." Consequently, we expect the association between being a sexual minority and religious decline is attenuated when it comes to prayer. 
H3: There will be little difference in changes in frequency of prayer between sexual minorities and heterosexuals or those reporting different-sex behaviors and attractions in emerging adulthood.

Finally, we address different ways of conceptualizing and operationalizing sexual minority status. Previous quantitative research has generally treated sexual attraction, behavior, and identity as the same concept and used them interchangeably, presumably due to a lack of multiple sexuality measures on many surveys. However, more recent research suggests that attraction, behavior, and identity are three spheres of sexuality that are related but not synonymous (Savin-Williams 2011). In particular, attraction and behavior may not be connected to the same identity conflicts that are inherent in a sexual minority identity label (Beaulieu-Prévost and Fortin 2015). Therefore, it is important to distinguish between identity, behavior, and attraction when possible. This study examines the distinct concepts of attraction, behavior, and identity to provide the best understanding of religious change among sexual minorities.

\section{Data and methods}

Data for this study come from Waves I and IV of both the National Longitudinal Study of Adolescent to Adult Health (Add Health) and the National Study of Youth and Religion (NSYR). Add Health is a schoolbased study that began in September 1994 and is a longitudinal sample of U.S. adolescents (to young adulthood). Add Health Wave I began with in-school questionnaires surveying 90,118 adolescents from 80 high schools and 52 middle schools (unequal probabilities of selection; Harries et al. 2009). In addition, a subset of those students ( $n$ $=20,745$ ) and their parents filled out an in-depth in-home interview survey at Wave I, which this study utilizes. Response rates are 79 percent for Wave I and 80 percent for Wave IV $(n=15,701)$. At Wave I respondents were 7 th-12th graders and by Wave IV, in 2008, they were 25-34 years of age. The Add Health sample was restricted to respondents who were interviewed at both Wave I and Wave IV and whose responses included data on religiosity, sexual identity, attraction, and behavior. The analytic sample using Add Health data varies between 12,056 and 12,852 . 
The NSYR began as a telephone survey in 2002-2003. A random sample of 3,290 U.S. adolescents, ages 13-17, and one of each of their parents were surveyed in Wave I. The response rate was 57 percent, according to the American Association for Public Opinion Research's Response Rate 4. Adolescent respondents were surveyed again in Wave IV, in 2013, when they were between 22 and 29 years of age. The Wave IV sample size is 2,071, an attrition rate of 37 percent from Wave I. Wave IV was administered primarily online. The NSYR sample was limited to respondents who were interviewed at both Waves I and IV and whose responses included data on religiosity, sexual identity, attraction, and behavior. The analytic sample varies between 1,459 and 2,059. See Smith and Denton (2008) for more information on the NSYR.

These surveys were selected for several reasons. Most importantly, both surveys contain data on sexual attraction, sex of sexual partners, and sexual identity/orientation. Additionally, they both ask about religious affiliation, religious service attendance, and prayer in Waves I and IV. This longitudinal feature provides religiosity at Wave I without relying on respondents' recall some years later. In addition, using both data sources allows us to test our hypotheses among different samples of emerging adults and ensure that our conclusions are not driven by the sampling approach of any one dataset (e.g., school-based sampling in Add Health). Missing data on control variables in both surveys were imputed across 20 data sets using the mi impute option in Stata. ${ }^{2}$

\section{Dependent Variables}

Both the Add Health and the NSYR asked respondents what their religion is in both Wave I and Wave IV. Response options included no religion as well as dozens of religions and Christian denominations. The first dependent variable assesses becoming religiously unaffiliated and is coded 1 for those who switched from religiously affiliated to no religious affiliation and 0 for those who remain affiliated with a religion. Respondents who were unaffiliated in Wave I are removed from the sample for the analyses of disaffiliation.

2. Missing data on religious affiliation is not imputed in the models of disaffiliation. However, missing data on religious affiliation control variables is imputed in the models of changes in attendance and prayer. 
Our second dependent variable in both the Add Health and the NSYR data measures change in religious service attendance between waves. Respondents provided their frequency of service attendance in seven categories ranging from never to more than once a week in both waves of the NSYR. In the Add Health, response categories ranged from never to once a week or more across four categories in Wave I, and from never to more than once a week across six categories in Wave IV. Within both datasets, these measures were standardized to have a mean of zero and a standard deviation of one. We then took the difference between respondent frequency of religious service attendance at Wave IV and Wave I (i.e., Wave IV-Wave I) to create the change measure.

Our final dependent variable measures change in frequency of prayer from Wave I to Wave IV in both the Add Health and the NSYR. Frequency of praying alone was measured in the NSYR with seven categories ranging from never to many times a day. In Wave I of the Add Health, frequency of prayer was measured in five categories ranging from never to at least once a day. in Wave IV, eight categories were used ranging from never to more than once a day. These measures were standardized to have a mean of zero and a standard deviation of one. Then, for each respondent, we took the difference between their Wave IV and Wave I frequency of prayer to create measures of change. In contrast to the disaffiliation variable, lower values on the change in prayer and attendance variables indicate declines in religiosity.

\section{Add Health Independent Variables}

Sexual orientation was measured using a single item from Wave IV that asked respondents to choose the description that best fits how they think about themselves: "100\% heterosexual; mostly heterosexual; bisexual; mostly homosexual; or 100\% homosexual." Preliminary analyses showed that "bisexual" and "mostly heterosexual" respondents do not differ significantly on the measures of religiosity. Likewise, "mostly homosexual" and "100\% homosexual" respondents do not differ from one another. Thus, in line with previous research (Everett and Mollborn 2013; Ueno 2010), we condense the original five categories into three: "heterosexual," "bisexual" (includes both "mostly heterosexual" and "bisexual"), and "gay" (includes "mostly homosexual" and "100\% homosexual"). 
Sexual behavior was measured with two items in Wave IV. The first, "Considering all types of sexual activity, with how many male partners have you ever had sex?" The second item was worded the same but asked about female sexual partners. These were recoded into four dummy variables: those who have had sexual relationships with individuals of a different sex, the same sex, same and different sex, and no sex partners.

Sexual attraction was measured using two items asked in Wave IV with a yes/no response option. These questions were: "are you romantically attracted to females?" and "are you romantically attracted to males?" These were recoded by respondent gender into four categories: attracted to individuals of a different sex, same sex, same and different sex, and no sexual attraction.

\section{NSYR Independent Variables}

Sexual orientation was measured using a single item from the Wave IV survey that asked respondents to choose the description that best fits them: Heterosexual (straight), bisexual, homosexual (gay or lesbian), asexual (not sexually attracted to others), and other. Due to small cell sizes, sexual orientation was coded as a dichotomous variable: heterosexual or not heterosexual $(0 / 1)$.

Sexual behavior was measured using a single item in Wave IV that asked respondents about the sex of their sexual partners in the past five years: Exclusively male, mostly male but some female, about as many male as female, mostly female but some male, exclusively female, no sex partners in the past five years, and other. ${ }^{3}$ Due to small cell sizes, sexual behavior was coded as a dichotomous variable: heterosexual or not heterosexual $(0 / 1){ }^{4}$

Sexual attraction was measured using a single item in Wave IV that asked respondents "Who are you sexually attracted to?" The response options were exclusively male, mostly male, both male and female,

3. Responses were limited to male, female, and transgender/queer for those with one partner over the previous five years.

4. Only two respondents reported having no sexual partners in the previous five years. These respondents were coded as not having same sex behaviors. Removing these two respondents from the sample instead does not affect the results. 
mostly female, exclusively female, other, and not sexually attracted to others. Due to small cell sizes, sexual attraction was coded as a dichotomous variable: heterosexual or not heterosexual $(0 / 1) .^{5}$

\section{Control Variables}

The same control variables are used with both the NSYR and Add Health. Unless otherwise specified, control variables are derived from Wave IV. Gender was measured with a dummy variable (female $=1$ ) and age with a continuous variable reflecting years of age. Race-ethnicity (Wave I)was coded as a series of dummy variables: non-Hispanic white (reference), non-Hispanic African American, Hispanic, non-Hispanic Asian or Pacific Islander, and other race (Asian is included in the "other race" category in NSYR models). Education was assessed with dummy variables for college degree and currently in college. Region was measured with a dummy variable indicating residing in the Southern region of the United States. In addition, we created dummy variables for whether the respondent lived with their parents at the time of the survey, if they were married, and if they had any children. Adolescent religious tradition (Wave I) is measured with dummy variables for evangelical Protestant (reference), mainline Protestant, black Protestant, Catholic, other religion, and unaffiliated (Steensland et al. 2000). ${ }^{6}$ Finally, we controlled for whether either of their parents had a college degree at Wave I, if the adolescent lived with married parents at Wave I, and how often their parents attended religious services at Wave I (four category variable ranging from never attended to once a week in Add Health, seven category variable ranging from never to more than once a week in NSYR).

5. The four respondents who reported not being sexually attracted to other people are removed from the sample for the models that include attraction. The nine respondents who reported being attracted to "other" types of people are coded as having non-heterosexual attraction.

6. Many of the Protestant affiliation response options in Wave I of the Add Health are too broad to create the different Protestant traditions as specified in the Steensland and colleagues (2000) classification system. As recent research shows (Smith et al. 2018), measures of self-identification as a "born again" or "evangelical Protestant" are highly correlated with evangelical affiliation. Consequently, we use affiliation in conjunction with the measure "Do you think of yourself as a Born-Again Christian." White Baptists, Lutherans, Methodists, Presbyterians, and "other Protestants" who identify as born-again are considered evangelical while those who do not are considered mainline (see Cheadle and Schwadel 2012). 
Table 1 displays descriptive statistics for both the Add Health and NSYR. ${ }^{7}$ The Add Health sample is largely heterosexual with 87 percent identifying their sexual orientation as such, whereas 11 percent are bisexual and about 2 percent identify as gay or lesbian at Wave IV. When reporting sexual behavior, 87 percent of the sample report exclusively different-sex partners, 1 percent report exclusively same-sex sexual partners, about 9 percent report sexual behavior with different- and same-sex partners, and 3 percent of the sample report no sexual partners by Wave IV. Regarding sexual attraction, 93 percent of the Add Health sample reported being exclusively attracted to individuals who had a different sex than their own, almost 2 percent reported experiencing sexual attraction to same-sex individuals, almost 5 percent reported sexual attraction to individuals of the same- and different-sex, and less than 1 percent report no sexual attraction in Wave IV. ${ }^{8}$ The

7. Fewer Add Health respondents switched from having a religious affiliation in Wave I to no affiliation in Wave IV. There are several potential reasons for this difference between the two sources of data, including the methods of identifying the samples (random digit dialing vs. school-based probability sample). The difference in age ranges also likely plays a role. The Add Health respondents are older-up to 21 years old in Wave I, as opposed to 17 in the NSYR sample; and up to 34 in Wave IV, as opposed to 29 in the NSYR. Thus, a larger proportion of the Add Health respondents had already disaffiliated in Wave I: the non-affiliation rate in Wave I is 13 percent in the Add Health sample and 12 percent in the NSYR. More importantly, fewer NSYR respondents had aged to the point of potentially returning to religion by Wave IV. Many relatively irreligious young adults return to religion as they age and have families of their own (Lim, MacGregor, and Putnam 2010; Wilson and Sherkat 1994). Indeed, in Wave IV of the Add Health, 16 percent of the younger respondents (ages 25-29) reported disaffiliating from religion, compared to only 11 percent of the older respondents (ages 30-34). We expect that the disaffiliation rate among NSYR respondents will also decline as they age.

8. In the Add Health sample, 63 of 252 respondents (25 percent) who report having experienced same-sex attraction have disaffiliated, 152 out of 680 respondents (22 percent) who report having same-sex and different-sex attractions have disaffiliated, and 14 out of 108 respondents (13 percent) who report no sexual attraction have disaffiliated, whereas 1,771 out of 12,868 respondents (14 percent) who report only different-sex attractions have disaffiliated. In addition, 32 out of 132 respondents (24 percent) who report exclusively same-sex sexual partners have disaffiliated, 254 of 1,285 respondents (20 percent) who report same- and different-sex sexual partners have disaffiliated, and 32 out of 369 respondents (.08 percent) who report no sexual partners have disaffiliated, compared to 1,683 of 12,122 respondents (14 
Table 1: Descriptive Statistics

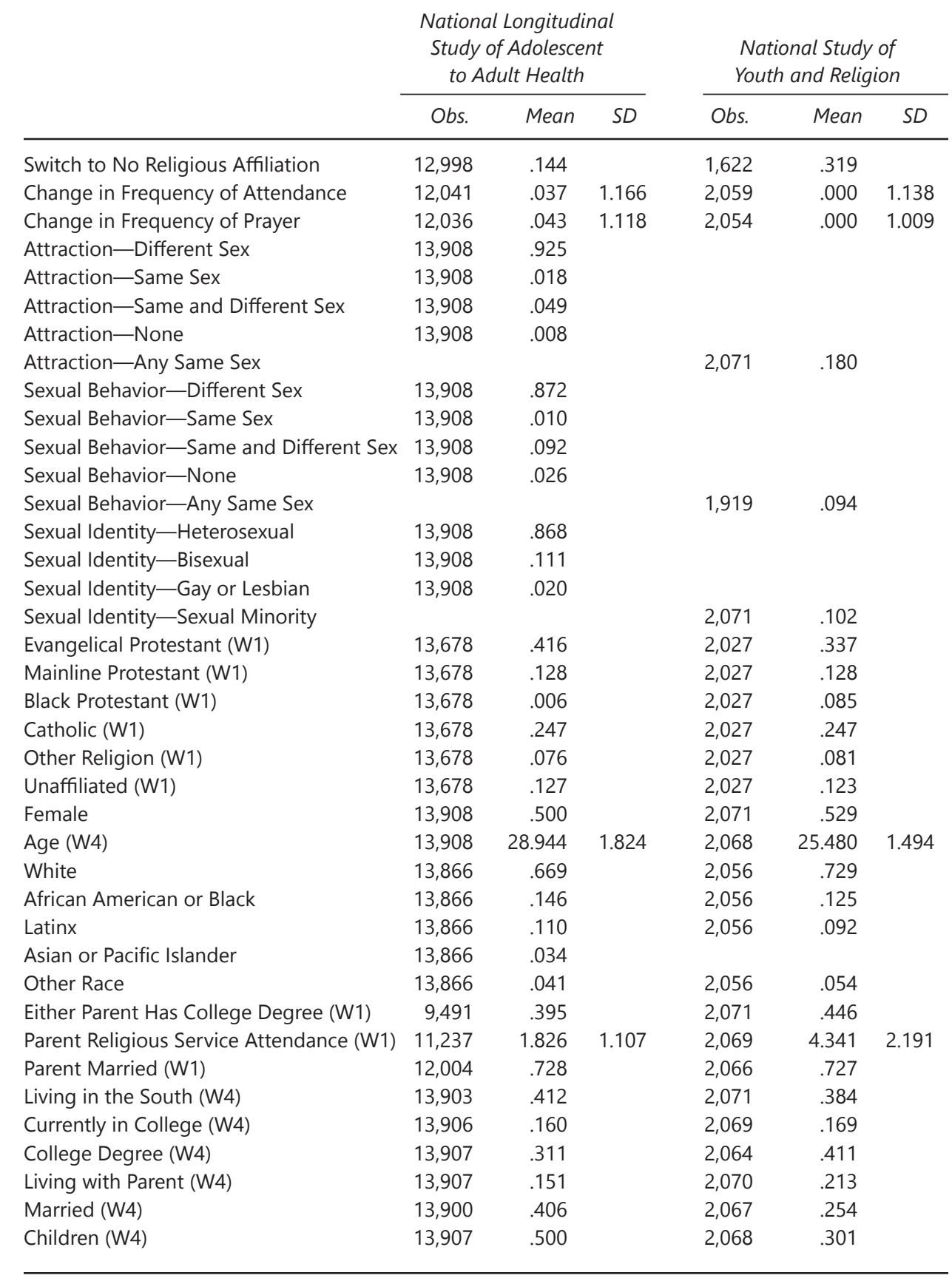

percent) who report exclusively different-sex sexual partners. Also in the Add Health, 70 out of 281 respondents ( 25 percent) who identify as gay or lesbian have disaffiliated and 385 of 1,549 respondents ( 25 percent) who identify as bisexual have disaffiliated, compared to 1,593 of 12,078 (13 percent) of those who had a heterosexual identity. 
NSYR data is also majority heterosexual with 10 percent identifying as a sexual minority (includes those identifying as gay, lesbian, or bisexual). In addition, 18 percent reported experiencing any same-sex attraction and 9 percent reported sexual behavior that included any same-sex partner. ${ }^{9}$

\section{Analytic Plan}

We use binary logistic regression models when becoming unaffiliated is the dependent variable, and OLS regression when modeling changes in frequency of service attendance and prayer. All models are weighted.

Causally speaking, the ideal approach would seem to be to model the effects of sexual identity/behavior/attraction on changes in religiosity using measures of sexuality from Wave I. That approach, however, is problematic for two reasons. First, many emerging adults who exhibit same-sex attractions and behaviors identified as heterosexual when they were adolescents (Glover, Galliher, and Lamere 2009; Herbenick et al. 2010; Savin-Williams and Diamond 2000). One reason for this is likely the heteronormativity prevalent within U.S. society that leads adolescents to struggle with developing a stigmatized sexual identity (Striepe and Tolman 2003). Second, a more pragmatic concern is that the sexual identity, behavior, and attraction questions were not included in Wave I of the NSYR, and sexual identity was not asked in Wave I of the Add Health. Our analyses, however, focus on changes in religiosity, and thus avoid conflating the findings with any existing religious differences between sexual minorities and other respondents in Wave I (see Appendices S4-S6 for analyses of religious differences in Wave I).

9. Within the NSYR, 140 of 327 respondents (43 percent) who report any same-sex attraction have disaffiliated, compared to 418 of 1,559 (27\%) of those who report only different-sex attraction. In addition, 71 of 159 respondents (45 percent) who report any same-sex behaviors have disaffiliated, compared to 466 of 1,588 (29 percent) of those who report only different-sex behaviors. The NSYR also had 80 respondents of 185 (43 percent) with non-heterosexual identities who have disaffiliated, compared to 478 of 1,701 (28 percent) who had a heterosexual identity and have disaffiliated. 


\section{Results}

Table 2 shows results for becoming unaffiliated between Waves I and IV by our three measures of sexuality (see Appendix S1 for control variable results). The first Add Health model (2-A) shows that sexual attraction is significantly associated with becoming unaffiliated. Specifically, the odds of disaffiliating are $\left(e^{.538}=1.71\right) 71$ percent greater for those who report same-sex attraction than for those who report exclusively experiencing attraction to different sex individuals; and the odds of becoming unaffiliated are 80 percent greater for those who report both same-sex and different-sex attraction than for those who report only experiencing attraction to different-sex individuals. Model 2-B includes sexual behaviors and shows that the odds of disaffiliation are 48 percent greater for emerging adults who report sexual activity with sameand different-sex partners than for those who report only different-sex sexual partners. Exclusively same-sex behavior, however, is not significantly associated with disaffiliation. In Model 2-C, we find that compared to heterosexuals, the odds of disaffiliation are 80 percent greater for those who identify as bisexual and 68 percent greater for those who identify as gay or lesbian.

Table 2 also reports results of becoming unaffiliated using NSYR data. Model 2-D shows that the odds of disaffiliation are 98 percent greater for those who report any same-sex attraction than those who report exclusively different-sex attraction. We find similar patterns among the two other measures of sexuality, with same-sex behavior associated with a 59 percent increase in the odds of disaffiliation (Model 2-E) and identifying as something other than heterosexual associated with a 96 percent increase in the odds of disaffiliation (Model 2-F). Taken together, the results in Tables 2 support the argument (Hypothesis 1) that sexual minorities are considerably more likely than heterosexual and different-sex attracted and partnered emerging adults to disaffiliate from organized religion. Additionally, the Add Health results partially support Hypothesis $1 \mathrm{~b}$ by showing that emerging adults who report both sameand different-sex behaviors are relatively likely to disaffiliate from religion but those who report only same-sex behaviors are not significantly different from those who report only different-sex behaviors.

Table 3 reports results from OLS models of change in religious service attendance (see Appendix S2 for control variable results). Model 3-A 


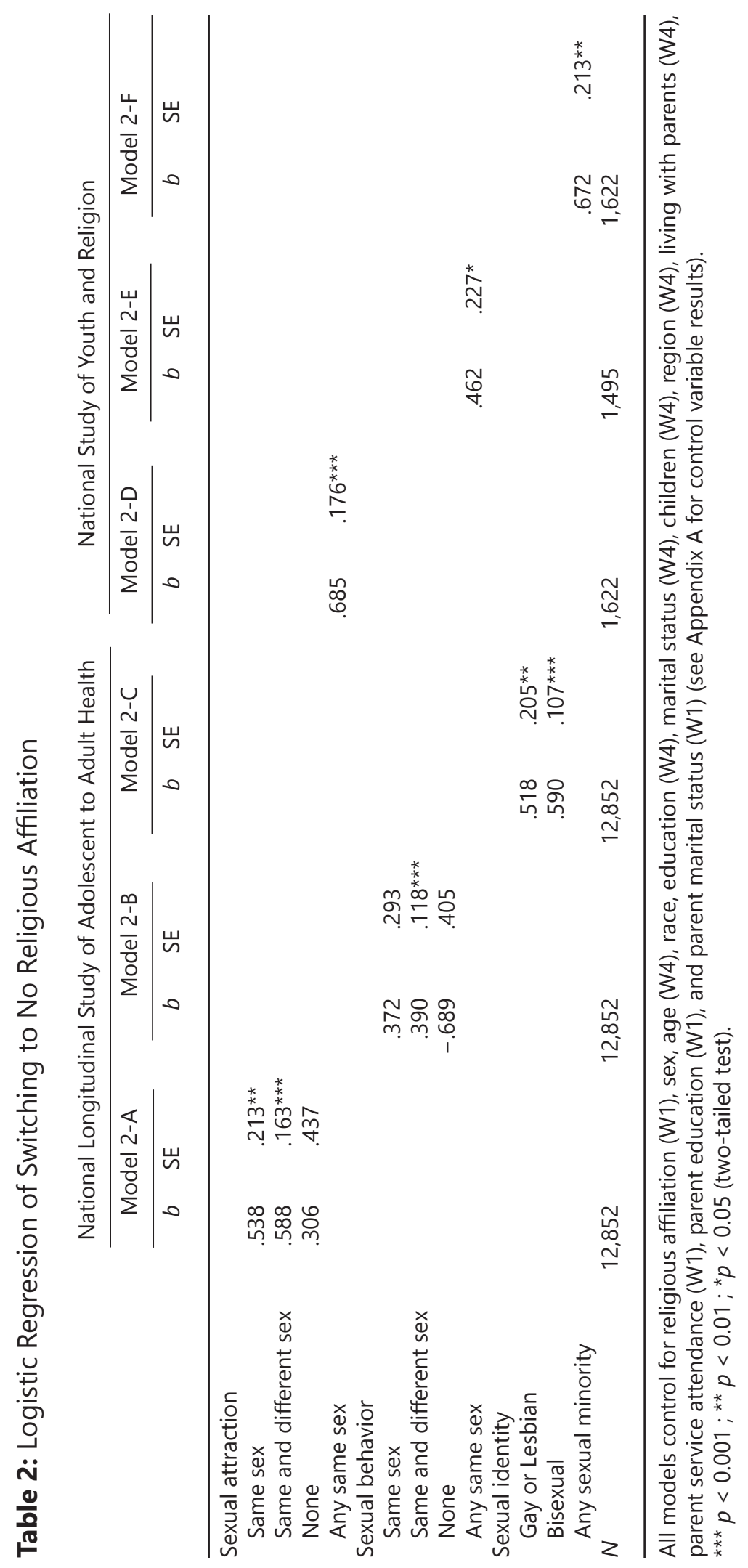




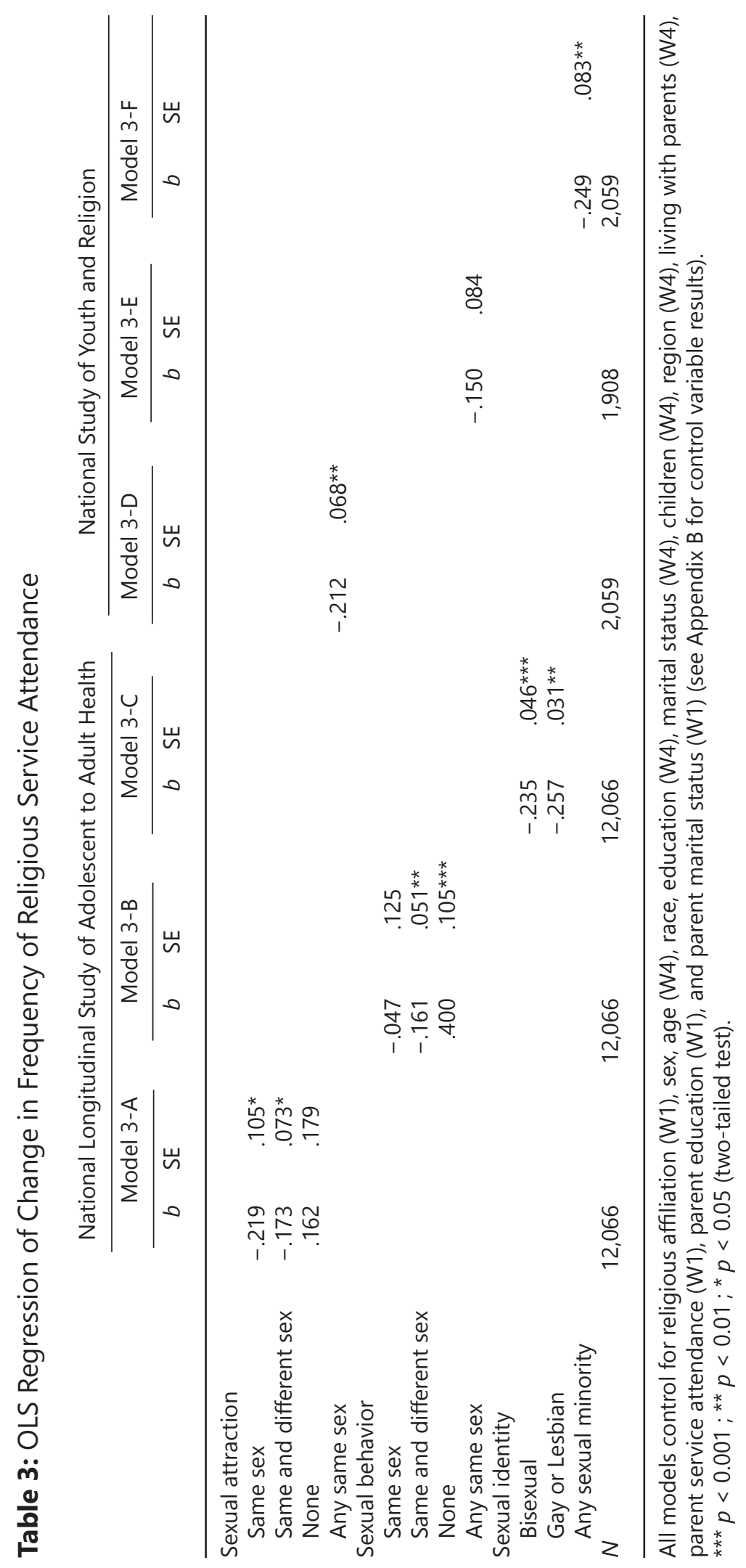


shows that, in the Add Health sample, same-sex attraction $(b=-.219)$ and attractions to individuals of the same- and a different-sex ( $b=-.173$ ) are both significantly associated with declines in service attendance. In Model 3-B, same- and different-sex sexual behavior $(b=-.161)$ is associated with a decline in religious service attendance while no sexual partners is associated with an increase in attendance $(b=.400)$. Similar to disaffiliation, however, exclusively same-sex behavior is not significantly associated with changes in attendance. This finding partially supports Hypothesis $2 \mathrm{~b}$. Model $3-\mathrm{C}$ shows that bisexual sexual identity $(b=-.235)$ and gay or lesbian sexual identity $(b=-.257)$ are both significantly associated with a decline in service attendance. Turning to the NSYR results, Model 3-D shows that same-sex attraction is significantly associated with a decline in service attendance $(b=-.212)$. Model 3-F shows that a non-heterosexual sexual identity such as gay, lesbian, or bisexual is significantly associated with a decline in religious service attendance $(b=-.249)$. These results largely support Hypothesis 2 .

Table 4 presents findings from OLS models of change in frequency of prayer (see Appendix S3 for control variable results). In the Add Health sample, we find that bisexual sexual identity (Model 4-C) has a small but significant association with declines in frequency of prayer from Wave I to Wave IV $(b=-.094)$. Neither sexual attraction (Model 4-A) nor behavior (Model 4-B) are significantly associated with changes in frequency of prayer in the Add Health sample. The final three models use the NSYR data to examine changes in prayer. Model 4-D shows that same-sex sexual attraction is associated with a moderate decrease in the frequency of prayer ( $b=-.173$ ). Neither same-sex behavior (Model 4-E) nor nonheterosexual identity (Model 4-F) are significantly associated with changes in frequency of prayer in the NSYR sample. These results provide mixed support for Hypothesis 3.

Overall, the results in Tables 2 to 4 show that nonheterosexual identities and both same-sex attraction and behavior are strongly and consistently associated with declines in participation in organized religion, both affiliation and attendance. In contrast, sexuality appears less relevant to frequency of prayer, with only same-sex attraction having a moderate association with declines in prayer in the NSYR sample and only bisexual identity having a small association with declines in prayer in the Add Health sample. 


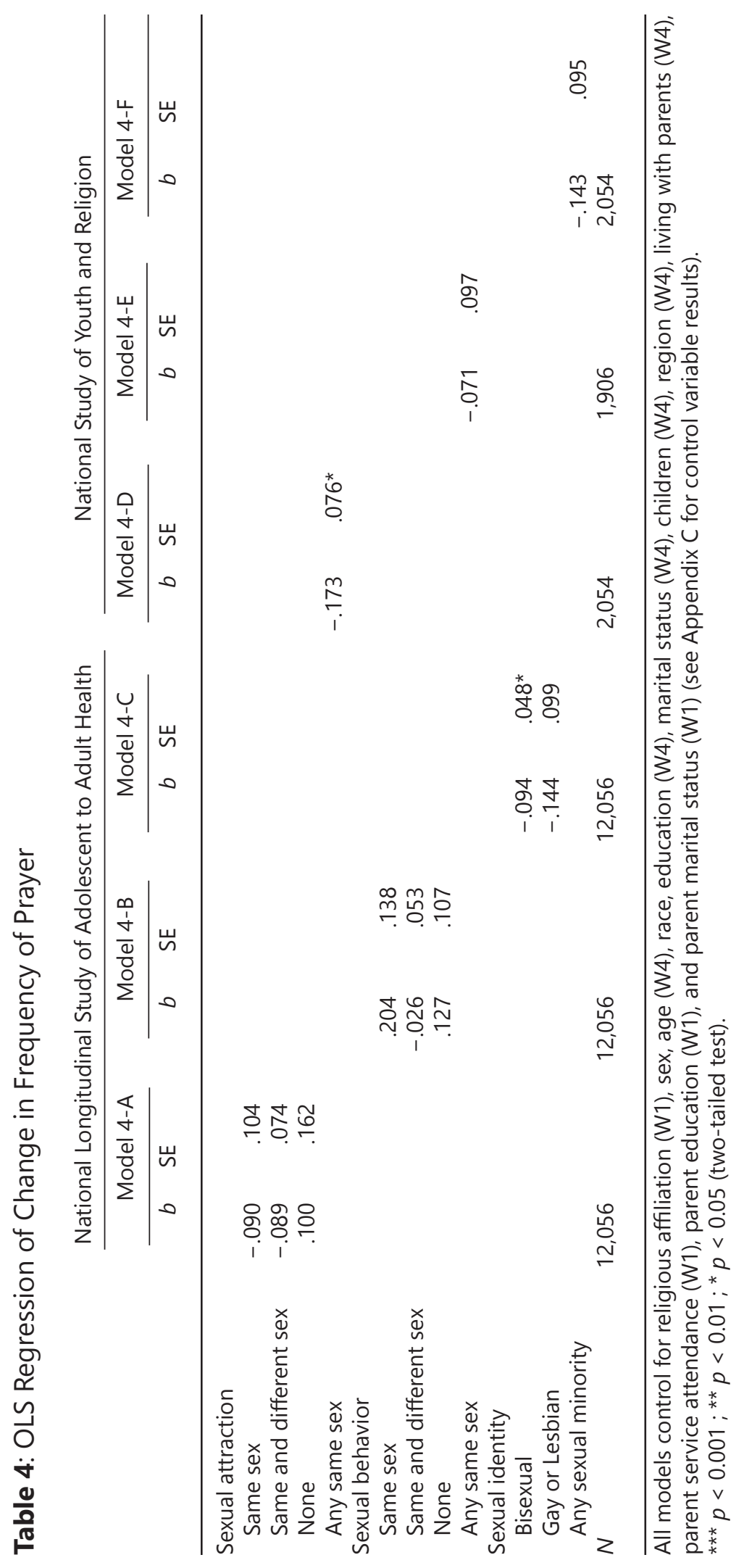




\section{Discussion}

Religion is a well-documented source of stigmatization for sexual minorities in the United States (e.g., Schwadel and Garneau 2019; Sherkat et al. 2011). This may be a contributing factor in why LGB individuals are more critical of religious institutions than their heterosexual peers (Sandstrom and Schwadel 2019). This study illustrates how this social context affects changes in LGB emerging adults' religiosity. This study also makes an important contribution by incorporating three measures of sexuality (attraction, behavior, and identity). Our findings illustrate that while these measures often have similar associations with religion outcomes, there are also notable differences.

We find strong support for our first hypothesis, that sexual minorities are more likely than heterosexuals to become unaffiliated in emerging adulthood. In both the NSYR and Add Health samples, sexual identity, behavior, and attraction are all associated with disaffiliation. For example, in the Add Health sample, we see notable increases in disaffiliation among those who identify as bisexual, those with attractions to sameand different-sex persons, and those who have previous sexual experience with same- and different-sex others.

Regarding service attendance, we find that those who report any same-sex attraction and those with a nonheterosexual sexual identity show greater declines in their religious service attendance compared to their exclusively different-sex attracted and heterosexual counterparts in the NSYR. Similarly, with the Add Health data, we find that those who have experienced same-sex attractions, same- and different-sex attractions, those who identify as gay or lesbian, and those who identify as bisexual all show greater declines in their religious service attendance compared to those who report exclusively different-sex attractions and individuals who identify as heterosexual. Overall, this largely supports our second hypothesis. By attending religious services less often, sexual minorities may avoid facing challenges from congregants that they perceive as hostile to their sexuality.

Both the becoming unaffiliated and attendance results highlight the importance of separating out those who report exclusively same-sex sexual partners from those who report same- and different-sex partners. The Add Health analyses show that those who report both same- and different-sex sexual partners are relatively likely to disaffiliate from religion 
and to decline in their religious service attendance. Emerging adults who report exclusively same-sex behaviors are not significantly different from those who report exclusively heterosexual behaviors. These results, which partially support Hypotheses $1 \mathrm{~b}$ and $2 \mathrm{~b}$, suggest that $\mathrm{a}$ single sexual minority category may miss key distinctions among sexual minorities. Previous research notes that within religious communities, bisexuals are viewed less favorably than their gay and lesbian peers, and their sexuality is considered even more of a choice (Sumerau et al. 2015; Toft 2012). The bisexual respondents in our sample may have experienced this stigmatization from their own religious communities and decided to leave. Our findings highlight the importance of examining bisexuals as a separate group, as most previous research has focused exclusively on monosexual sexual minorities (gay or lesbian) or combined lesbian, gay, and bisexual individuals into one sexual minority category (see Scheitle and Wolf 2017 for an exception). That is, that bisexuals, while having some of the same patterns as gay men and lesbian women, may be even more likely than their lesbian and gay peers to leave unwelcoming religions.

We find some support for our third hypothesis regarding changes in frequency of prayer. Sexual attraction within Add Health, sexual behavior within both datasets, and sexual identity within the NSYR were not significantly associated with changes in frequency of prayer from Wave I to Wave IV, as predicted. This adds support to the idea that religious sexual minorities may choose more private religious practices such as prayer due to the stigmatization they often face within religious groups. Yet our analyses also show that any same-sex attraction (in the NSYR) and bisexual sexual identity (in the Add Health) are moderately associated with declines in prayer. It may be that those who report any samesex attraction (as opposed to those who report sexual minority behaviors or identities) have not yet found a way to reconcile these feelings with their religiosity and thus pray less often. Regarding the bisexuality finding, due to monosexism and biphobia within some religious communities, bisexuals may choose to not only disaffiliate from religion but also to discontinue private practices such as prayer (Sumerau et al. 2019; Toft 2012). Though we again reiterate that this association is quite small, despite being statistically significant. 


\section{Conclusions}

This study contributes to a growing body of research on the religious experiences of sexual minorities in several ways. We use two longitudinal data sources to explore how sexuality predicts the likelihood of decreasing religiosity in emerging adulthood. We do this to ensure our conclusions are not driven by the unique aspects of any one data source. We also operationalize sexuality with three measures-attraction, behavior, and identity. While these are strengths of this project, there are several limitations and opportunities for future research that need to be addressed.

Perhaps most importantly, neither the Add Health nor NSYR surveys include all three sexuality measures in the first wave. While we address the causal assumptions inherent in our models through ancillary analyses (see Appendices S4-S6) and by focusing on changes in religiosity, future research would benefit from the inclusion of multiple sexuality measures across time. One limitation of the NSYR is the smaller sample that meant we had only one "nonheterosexual" group for analysis. In addition, due to the small number of transgender respondents in the NSYR and the lack of gender diversity questions in the Add Health, we are unable to include this group in our analyses. We included two data sources in an effort to address the limitations found within each but a longitudinal data source that overcomes these limitations would help advance this area of research.

Future research should continue to include multiple measures of sexuality as the above results show that different operationalizations of sexual minority status have different associations with changes in religiosity. In addition, future research could expand on the present study by including samples of middle-age and older adult populations and compare them to contemporary emerging adults, as well as follow up with contemporary emerging adults in later life to examine patterns of religiosity across the life course. Finally, future research should also address how gender affects the relationship between sexuality and religiosity. Previous research suggests that there is a gendered dynamic to religion (Miller and Hoffman 1995), therefore, studying how gender interacts with multiple measures of sexuality across various types of religious participation would make an important contribution to the literature.

In sum, we find that contemporary sexual minority emerging adults 
are relatively likely to decline in their public religious practices-both affiliation and service attendance-even though many religious groups are becoming more welcoming of sexual minorities (Cadge et al. 2008; Pew Research Center 2015). On the other hand, there is little significant difference in changes in prayer by sexual identity, behavior, or attraction. This may be partially explained by the more individualistic nature of prayer as a form of religious practice; namely, that it does not necessary involve others that may be stigmatizing towards sexual minorities. Lastly, sexual minorities are not a monolithic community. We find support for the inclusion of multiple measures of sexuality as attraction, behavior, and identity offer important and sometimes differing insights into the religious practices of sexual minorities.

Acknowledgments: We would like to thank the anonymous reviewers and the Editor of Journal for the Scientific Study of Religion for their helpful comments, and the University of Nebraska-Lincoln's Department of Sociology for its financial support that made this research possible.

\section{References}

Abramowitz, Alan I. and Kyle L. Saunders. 2008. Is polarization a myth? The Journal of Politics 70(2):542-55.

Andersen, Robert and Tina Fetner. 2008. Economic inequality and intolerance: Attitudes toward homosexuality in 35 democracies. American Journal of Political Science 52(4):942-58.

Arnett, Jeffrey Jensen. 2000. Emerging adulthood: A theory of development from the late teens through the twenties. American Psychologist 55(5):469-80.

Arnett, Jeffrey Jensen and Lene Arnett Jensen. 2002. A congregation of one: Individualized religious beliefs among emerging adults. Journal of Adolescent Research 17:451-67.

Barringer, Mandi Nicole, David A., Gay, and John P. Lynxwiler. 2013. Gender, religiosity, spirituality, and attitudes toward homosexuality. Sociological Spectrum 33(3):240-57.

Barry, Carolyn McNamara, Larry Nelson, Sahar Davarya, and Shirene Urry. 2010. Religiosity and spirituality during the transition to adulthood. International Journal of Behavioral Development 34(4):311-24.

Barton, Bernadette. 2012. Pray the gay away: The extraordinary lives of bible belt gays. New York: New York University Press.

Beaulieu-Prévost, D. and M. Fortin. 2015. The measurement of sexual orientation: Historical background and current practices. Sexologies 24(1):e15-19. 
Burge, Ryan P. 2018. To be of one mind?: Integrating an LGB orientation with evangelical beliefs. Politics, Groups, and Identities. https://doi.org/10.1080/2156 5503.2018.1518784.

Cadge, Wendy, Laura R. Olson, and Christopher Wiseman. 2008. How denominational resources influence debate about homosexuality in mainline protestant congregations. Sociology of Religion 69(2):187-207.

Calzo, Jerel P., Toni C. Antonucci, Vickie M. Mays, and Susan D. Cochran. 2011. Retrospective recall of sexual orientation identity development among gay, lesbian, and bisexual adults. Developmental Psychology 47(6):1658-73.

Cheadle, Jacob E. and Philip Schwadel. 2012. The 'friendship dynamics of religion,' or the 'religious dynamics of friendship'? A social network analysis of adolescents who attend small schools. Social Science Research 41:1198- 1212.

Cornwall, Marie, Stan L. Albrecht, Perry H. Cunningham, and Brian L. Pitcher. 1986. The dimensions of religiosity: A conceptual model with an empirical test. Review of Religious Research 27(3):226-244.

Cotton, Sian, Kathy Zebracki, Susan L. Rosenthal, Joel Tsevat, and Dennis Drotar. 2006. Religion/spirituality and adolescent health outcomes: A review. Journal of Adolescent Health 38:472-80.

Everett, Bethany and Stefanie Mollborn. 2013. Differences in hypertension by sexual orientation among U.S. young adults. Journal of Community Health 38:588-96.

Flores, Andrew R. 2014. National trends in public opinion on LGBT rights in the United States. The Williams Institute. https://williamsinstitute.law.ucla.edu/wp-content/ uploads/POP-natl-trends-nov-2014.pdf (accessed July 17, 2019).

Floyd, Frank J. and Roger Bakeman. 2006. Coming-out across the life course: Implications of age and historical context. Archives of Sexual Behavior 35(3):287-96.

Fuist, Todd Nicholas, Laurie Cooper Stoll, and Fred Kniss. 2012. Beyond the liberalconservative divide: Assessing the relationship between religious denominations and their associated LGBT organizations. Qualitative Sociology 35(1):65-87.

Gates, Gary. 2010. Sexual minorities in the 2008 General Social Survey: Coming out and demographic characteristics. The Williams Institute. https://williamsinstitute. law.ucla.edu/wp-content/uploads/Gates-Sexual-Minorities-2008-GSSOct-2010. pdf (accessed July 17, 2019).

Glock, Charles Y. 1962. On the study of religious commitment. Religious Education 57(4):S98-S110.

Glover, Jenna A., Renee V. Galliher, and Trenton G. Lamere. 2009. Identity development and exploration among sexual minority adolescents: Examination of a multidimensional model. Journal of Homosexuality 56(1):77-101.

Harris, Kathleen M., Carolyn T. Halpern, Eric Whitsel, Jon Hussey, Joyce Tabor, Pamela Entzel, and J. Richard Udry. 2009. The national longitudinal study of adolescent to adult health: Research design. http://www.cpc.unc.edu/projects/addhealth/ design (accessed July 27, 2019).

Heath, Melanie. 2012. One marriage under God: The campaign to promote marriage in America. New York: New York University Press. 
Herbenick, Debby, Michael Reece, Vanessa Schick, Stephanie A. Sanders, Brian Dodge, and J. Dennis Fortenberry. 2010. Sexual behavior in the United States: Results from a national probability sample of men and women ages 14-94. The Journal of Sexual Medicine 7(s5):255-65.

Lim, Chaeyoon, Carol Ann MacGregor, and Robert D. Putnam. 2010. Secular and liminal: Discovering heterogeneity among religious nones. Journal for the Scientific Study of Religion 49(4):596-618.

Mahaffy, Kimberly. 1996. Cognitive dissonance and its resolution: A study of lesbian Christians. Journal for the Scientific Study of Religion. 35(4):392-402.

Miller, Alan S. and John P. Hoffmann. 1995. Risk and religion: An explanation of gender differences in religiosity. Journal for the Scientific Study of Religion 34(1):63-75.

Morgan, Elizabeth M. 2013. Contemporary issues in sexual orientation and identity development in emerging adulthood. Emerging Adulthood 1(1):52-66.

Munson, Ziad W. 2009. The making of pro-life activists: How social movement mobilization works. Chicago, IL: University of Chicago Press.

Page, Mathew J. L., Kristin M. Lindahl, and Neena M. Malik. 2013. The role of religion and stress in sexual identity and mental health among lesbian, gay, and bisexual youth. Journal of Research on Adolescence 23(4):665-77.

Pew Research Center. 2014a. Religious landscape study. Pew Research Center's Religion \& Public Life Project. http://www.pewforum.org/religious-landscapestudy/ (accessed on December 31, 2019).

Pew Research Center. 2014b. National Congregations Study finds more church acceptance of gays and lesbians. https://www.pewresearch.org/facttank/2014/09/25/new-study-finds-a-greater-church-acceptance-ofgays-andlesbians-2/ (accessed on December 31, 2019).

Pew Research Center. 2015. Where Christian Churches, Other Religions Stand on Gay Marriage. https://www.pewresearch.org/fact-tank/2015/12/21/wherechristian-churches-stand-on-gay-marriage/ (accessed July 17, 2019).

Pew Research Center. 2017. 5 Key Findings about LGBT Americans. www. pewresearch.org/fact-tank/2017/06/13/5-keyfindings-about-lgbt-americans/ (accessed July 17, 2019).

Putnam, Robert D. and David E. Campbell. 2010. American grace: How religion divides and unites us. New York, NY: Simon \& Schuster, Inc.

Sandstrom, Aleksandra and Philip Schwadel. 2019. Lesbian, gay and bisexual Americans are more critical of churches than straight adults are. https:// www.pewresearch.org/fact-tank/2019/06/13/lesbian-gay-and-bisexualamericansare-more-critical-of-churches-than-straight-adults-are/ (accessed August 28, 2019).

Savin-Williams, Ritch C. 2011. Identity development among sexual-minority youth. In the Handbook of identity theory and research, edited by S. J. Schwartz, K. Luyckx, V. L. Vignoles, pp. 671-89. New York, NY: Springer Science + Business Media.

Savin-Williams, Ritch C. and Lisa M. Diamond. 2000. Sexual identity trajectories among sexual-minority youths: Gender comparisons. Archives of Sexual Behavior 29(6):607-27. 
Scheitle, Christopher P. and Julia Kay Wolf. 2017. The religious origins and destinations of individuals identifying as a sexual minority. Sexuality \& Culture 21:719-40.

Schwadel, Philip. 2011. The effects of education on Americans' religious practices, beliefs, and affiliations. Review of Religious Research 53(2):161-82.

Schwadel, Philip and Christopher R. H. Garneau. 2019. Sectarian religion and political tolerance in the united states. Sociology of Religion 80(2):168-93.

Schwartz, Seth J., Byron L. Zamboanga, Koen Luyckx, Alan Meca, and Rachel A. Ritchie. 2013. Identity in emerging adulthood: Reviewing the field and looking forward. Emerging Adulthood 1(2):96-113.

Sherkat, Darren E. 2002. Sexuality and religious commitment in the united states: An Empirical Examination. Journal for the Scientific Study of Religion 41(2):313-23.

Sherkat, Darren E. 2016. Sexuality and religious commitment revisited: Exploring the religious commitments of sexual minorities, 1991-2014. Journal for the Scientific Study of Religion 55(4):756-69.

Sherkat, Darren E., Melissa Powell-Williams, Gregory Maddox, and Kylan Mattias de Vries. 2011. Religion, politics, and support for same-sex marriage in the united states, 1988-2008. Social Science Research 40(1):167-80.

Smith, Christian and Melinda Lundquist Denton. 2005. Soul searching: The Religious and spiritual lives of American teenagers. NY: Oxford University Press.

Smith, Christian, and Melinda Lundquist Denton. 2008. Methodological Design and Procedures for the National Study of Youth and Religion (NSYR) Longitudinal Telephone Survey (Waves 1, 2, \& 3). https://youthandreligion.nd.edu/ assets/102496/master just methods 1112 2008.pdf (accessed July 27, 2019).

Smith, Gregory A., Elizabeth Podrebarac Sciupac, Claire Gecewicz, and Conrad Hackett. 2018. Comparing the RELTRAD and born-again/evangelical selfidentification approaches to measuring American Protestantism. Journal for the Scientific Study of Religion 57(4):830-47.

Steensland, Brian, Jerry Z. Park, Mark D Regnerus, Lynn D Robinson, W. Bradford Wilcox, and Robert D. Woodberry. 2000. The measure of American religion: Toward improving the state of the art. Social Forces 79:291-18.

Stone, Amy L. 2016. The impact of anti-gay politics on the LGBTQ movement. Sociology Compass 10(6):459-67.

Striepe, Meg I. and Deborah L. Tolman. 2003. Mom, Dad, I'm Straight: The coming out of gender ideologies in adolescent sexual-identity development. Journal of Clinical Child \& Adolescent Psychology 32(4):523-30.

Sumerau, J. E., Ryan T. Cragun, and Lain A. B. Mathers. 2015. Contemporary religion and the cisgendering of reality. Social Currents 3(3):293-311.

Sumerau, J. E., Lain A. B. Mathers, and Nik Lampe. 2019. Learning from the religious experiences of Bi+ Trans people. Symbolic Interaction 42(2):179-201.

Thomas, Jeremy N. and Andrew L. Whitehead. 2015. Evangelical elites' antihomosexuality narratives as a resistance strategy against attribution effects. Journal for the Scientific Study of Religion 54(2):345-362.

Thumma, Scott. 1991. Negotiating a religious identity: The case of the gay evangelical. Sociological Analysis 52(4): 333-47. 
Toft, Alex, 2012. Bisexuality and Christianity: Negotiating disparate identities in church life. In The Ashgate research companion to contemporary religion and sexuality, edited by S. J. Hunt and A. K. T. Yip, pp. 189-203. New York, NY: Routledge.

Trinitapoli, Jenny and Stephen Vaisey. 2009. The transformative role of religious experience: the case of short-term missions. Social Forces 88(1):121-46.

Uecker, Jeremy E., Mark D. Regnerus, and Margaret L. Vaaler. 2007. Losing my religion: The social sources of religious decline in early adulthood. Social Forces 85(4):1667-92.

Ueno, Koji. 2010. Same-sex experience and mental health during the transition between adolescence and young adulthood. The Sociological Quarterly 51:484-510.

Wedow, Robbee, Landon Schnabel, Lindsey K. D. Wedow, and Mary Ellen Konieczny. 2017. 'I'm Gay and I'm Catholic': Negotiating two complex identities at a catholic university. Sociology of Religion 78(3):289-317.

Whitehead, Andrew L. 2018. Homosexuality, religion, and the family: The effects of religion on Americans' appraisals of the parenting abilities of same-sex couples. Journal of Homosexuality 65(1):42-65.

Williams, Jean Calterone. 2011. Battling a 'sex-saturated society': The abstinence movement and the politics of sex education. Sexualities 14(4):416-43.

Wilson, John and Darren E. Sherkat. 1994. Returning to the fold. Journal for the Scientific Study of Religion 33(2):148-61.

Wolkomir, Michelle. 2006. Be Not Deceived: The Sacred and Sexual Struggles of Gay and Ex-Gay Christian Men. New Jersey: Rutgers University Press.

Woodell, Brandi, Emily Kazyak, and D'Lane Compton. 2015. Reconciling LGB and Christian identities in the rural south. Social Sciences 4(3):859-78.

Yip, Andrew Kam-Tuck. 1997. Attacking the attacker: Gay Christians talk back. British Journal of Sociology 48(1): 113-27.

Supporting information attached to this article.

Appendix S1. Control Variable Results from Logistic Regression of Switching to No Religious Affiliation

Appendix S2. Control Variable Results from OLS Regression of Change in Frequency of Religious Service Attendance

Appendix S3. Control Variable Results from OLS Regression of Change in Frequency of Prayer

Appendix S4. Logistic Regressions of No Religious Affiliation in Wave 1

Appendix S5. OLS Regression of Frequency of Religious Service Attendance in Wave 1

Appendix S6. OLS Regression of Frequency of Prayer in Wave 1 
Appendix S1. Control Variable Results from Logistic Regression of Switching to No Religious Affiliation

\begin{tabular}{|c|c|c|c|c|c|c|c|c|c|c|c|c|}
\hline & \multicolumn{6}{|c|}{ National Longitudinal Study of Adolescent to Adult Health } & \multicolumn{6}{|c|}{ National Study of Youth and Religion } \\
\hline & \multicolumn{2}{|c|}{ Model 2-A } & \multicolumn{2}{|c|}{ Model 2-B } & \multicolumn{2}{|c|}{ Model 2-C } & \multicolumn{2}{|c|}{ Model 2-D } & \multicolumn{2}{|c|}{ Model 2-E } & \multicolumn{2}{|c|}{ Model 2-F } \\
\hline & $\mathrm{b}$ & se & $\mathrm{b}$ & se & $\mathrm{b}$ & se & $\mathrm{b}$ & se & $\mathrm{b}$ & se & $\mathrm{b}$ & se \\
\hline Intercept & 1.25 & $.641 *$ & 1.19 & .652 & 1.17 & .644 & 1.600 & $.758 *$ & 1.961 & $.776^{*}$ & 1.653 & $.753 *$ \\
\hline Mainline Protestant & .608 & $.103 * * *$ & .608 & $.103 * * *$ & .605 & $.103 * * *$ & .817 & $.208 * * *$ & .722 & $.213 * * *$ & .819 & $.206 * * *$ \\
\hline Black Protestant & -.631 & .535 & -.609 & .533 & -.612 & .533 & .000 & .498 & -.076 & .498 & .000 & .484 \\
\hline Catholic & .265 & $.100 * *$ & .258 & $.098 * *$ & .258 & $.098 * *$ & .064 & .176 & .006 & .184 & .054 & .176 \\
\hline Other Religion & .700 & $.139 * * *$ & .707 & $.142 * * *$ & .688 & $.140 * * *$ & .170 & .231 & .175 & .244 & .167 & .229 \\
\hline Female & -.330 & $.076 * * *$ & -.327 & $.077 * * *$ & -.391 & $.078 * * *$ & -.423 & $.142 * *$ & -.373 & $.142 * *$ & -.375 & $.138 * *$ \\
\hline Age & -.073 & $.021 * * *$ & -.070 & $.022 * * *$ & -.071 & $.021 * * *$ & -.048 & .049 & -.069 & .050 & -.049 & .049 \\
\hline African American & -.730 & $.139 * * *$ & -.736 & $.139 * * *$ & -.710 & $.140 * * *$ & -.721 & .416 & -.676 & .413 & -.712 & .400 \\
\hline Latinx & -.311 & $.126 * *$ & -.297 & $.127 *$ & -.293 & $.127 *$ & -.273 & .254 & -.252 & .260 & -.285 & .254 \\
\hline Asian or Pacific Islander & -.685 & $.197 * * *$ & -.658 & $.195 * * *$ & -.686 & $.195 * * *$ & & & & & & \\
\hline Other Race & -.118 & .175 & -.119 & .177 & -.116 & .176 & .141 & .295 & .142 & .319 & .128 & .293 \\
\hline Parent College Degree & .057 & .092 & .045 & .092 & .043 & .092 & .169 & .150 & .195 & .154 & .180 & .149 \\
\hline Parent Attendance & -.288 & $.038 * * *$ & -.282 & $.038 * * *$ & -.284 & $.038 * * *$ & -.230 & $.035 * * *$ & -.209 & $.036 * * *$ & -.234 & $.035 * * *$ \\
\hline Parent Married & -.007 & .092 & -.013 & .094 & -.014 & .093 & -.205 & .160 & -.251 & .163 & -.205 & .159 \\
\hline Living in the South & -.285 & $.083 * * *$ & -.295 & $.082 * * *$ & -.280 & $.083 * * *$ & .040 & .144 & .110 & .150 & .032 & .144 \\
\hline Currently in College & .141 & .098 & .137 & .098 & .126 & .098 & .114 & .179 & .167 & .186 & .118 & .180 \\
\hline College Degree & .027 & .091 & .033 & .091 & .027 & .091 & -.550 & $.157 * * *$ & -.485 & $.163 * *$ & -.545 & $.156 * * *$ \\
\hline Living with Parent & -.355 & $.116^{* *}$ & -.328 & $.115^{* *}$ & -.347 & $.116^{* *}$ & -.319 & .176 & -.301 & .187 & -.305 & .176 \\
\hline Married & -.472 & $.088 * * *$ & -.484 & $.088 * * *$ & -.461 & $.088 * * *$ & -.408 & $.182 *$ & -.494 & $.184 * *$ & -.379 & $.182 *$ \\
\hline Children & -.298 & $.088 * * *$ & -.320 & $.088 * * *$ & -.292 & $.089 * * *$ & -.425 & $.175 *$ & -.485 & $.174 * *$ & -.467 & $.174 * *$ \\
\hline
\end{tabular}

Notes: See Table 2 for attraction, behavior, and sexual identity results.

$* * * \mathrm{p}<0.001, * * \mathrm{p}<0.01, * \mathrm{p}<0.05$ (two-tailed test) 
Appendix S2. Control Variable Results from OLS Regression of Change in Frequency of Religious Service Attendance

\begin{tabular}{|c|c|c|c|c|c|c|c|c|c|c|c|c|}
\hline & \multicolumn{6}{|c|}{ National Longitudinal Study of Adolescent to Adult Health } & \multicolumn{6}{|c|}{ National Study of Youth and Religion } \\
\hline & \multicolumn{2}{|c|}{ Model 3-A } & \multicolumn{2}{|c|}{ Model 3-B } & \multicolumn{2}{|c|}{ Model 3-C } & \multicolumn{2}{|c|}{ Model 3-D } & \multicolumn{2}{|c|}{ Model 3-E } & \multicolumn{2}{|c|}{ Model 3-F } \\
\hline & $\mathrm{b}$ & se & $\mathrm{b}$ & se & $\mathrm{b}$ & se & $\mathrm{b}$ & se & $\mathrm{b}$ & se & $\mathrm{b}$ & se \\
\hline Intercept & -1.82 & $.247 * * *$ & -1.78 & $.246 * * *$ & -1.78 & $.247 * * *$ & -.152 & .306 & -.284 & .314 & -.168 & .306 \\
\hline Mainline Protestant & .026 & .044 & .027 & .044 & .028 & .044 & -.197 & $.087 *$ & -.112 & .090 & -.197 & $.087 *$ \\
\hline Black Protestant & -.059 & .160 & -.072 & .158 & -.066 & .159 & .023 & .170 & .056 & .181 & .016 & .170 \\
\hline Catholic & -.102 & $.037 * *$ & -.096 & $.037 * *$ & -.096 & $.037 * *$ & -.082 & .081 & -.017 & .084 & -.080 & .081 \\
\hline Other Religion & .114 & $.054 *$ & .115 & $.053 *$ & .120 & $.054 *$ & .288 & $.103 * *$ & .291 & $.111^{* *}$ & .293 & $.103 * *$ \\
\hline Unaffiliated & .643 & .860 & .623 & .849 & .630 & .866 & .762 & $.090 * * *$ & .816 & $.094 * * *$ & .763 & $.090 * * *$ \\
\hline Female & .102 & $.029 * * *$ & .108 & $.029 * * *$ & .125 & $.030 * * *$ & -.030 & .057 & -.043 & .058 & -.042 & .055 \\
\hline Age & .072 & $.008 * * *$ & .070 & $.008 * * *$ & .071 & $.008 * * *$ & .019 & .020 & .024 & .020 & .019 & .020 \\
\hline African American & .207 & $.045 * * *$ & .215 & $.045 * * *$ & .201 & $.045 * * *$ & .494 & $.148 * * *$ & .527 & $.161 * * *$ & .501 & $.148 * * *$ \\
\hline Latinx & .131 & $.051 * *$ & .125 & $.051 * *$ & .126 & $.050 * *$ & .185 & .103 & .188 & .110 & .190 & .104 \\
\hline Asian or Pacific Islander & .068 & .073 & .057 & .072 & .069 & .073 & & & & & & \\
\hline Other Race & .138 & .075 & .140 & .075 & .140 & .075 & -.001 & .141 & -.021 & .155 & .004 & .141 \\
\hline Parent College Degree & -.036 & .037 & -.033 & .038 & -.032 & .037 & -.147 & $.062 *$ & -.135 & $.064 *$ & -.154 & $.062 * *$ \\
\hline Parent Attendance & -.250 & $.015 * * *$ & -.252 & $.015 * * *$ & -.252 & $.015^{* * *} *$ & -.102 & $.014 * * *$ & -.112 & $.015^{* * *}$ & -.100 & $.014 * * *$ \\
\hline Parent Married & -.028 & .039 & -.027 & .039 & -.026 & .038 & .044 & .064 & .046 & .067 & .048 & .064 \\
\hline Living in the South & .031 & .031 & .035 & .031 & .030 & .031 & .031 & .059 & .018 & .061 & .036 & .059 \\
\hline Currently in College & .026 & .038 & .024 & .038 & .029 & .038 & .020 & .073 & -.018 & .076 & .018 & .073 \\
\hline College Degree & .102 & $.034 * *$ & .096 & $.034 * *$ & .099 & $.034 * *$ & .187 & $.064 * *$ & .138 & $.066^{*}$ & .188 & $.063 * *$ \\
\hline Living with Parent & .084 & $.043 *$ & .069 & .043 & .081 & .042 & .075 & .068 & .025 & .074 & .075 & .068 \\
\hline Married & .211 & $.032 * * *$ & .220 & $.032 * * *$ & .203 & $.032 * * *$ & .394 & $.070 * * *$ & .463 & $.072 * * *$ & .387 & $.070 * * *$ \\
\hline Children & .118 & $.034 * * *$ & .135 & $.034 * * *$ & .115 & $.034 * * *$ & .059 & .072 & .089 & .073 & .067 & .072 \\
\hline
\end{tabular}

Notes: See Table 3 for attraction, behavior, and sexual identity results.

$* * * \mathrm{p}<0.001, * * \mathrm{p}<0.01, * \mathrm{p}<0.05$ (two-tailed test) 
Appendix S3. Control Variable Results from OLS Regression of Change in Frequency of Prayer

\begin{tabular}{|c|c|c|c|c|c|c|c|c|c|c|c|c|}
\hline & \multicolumn{6}{|c|}{ National Longitudinal Study of Adolescent to Adult Health } & \multicolumn{6}{|c|}{ National Study of Youth and Religion } \\
\hline & \multicolumn{2}{|c|}{ Model 4-A } & \multicolumn{2}{|c|}{ Model 4-B } & \multicolumn{2}{|c|}{ Model 4-C } & \multicolumn{2}{|c|}{ Model 4-D } & \multicolumn{2}{|c|}{ Model 4-E } & \multicolumn{2}{|c|}{ Model 4-F } \\
\hline & $\mathrm{b}$ & se & $\mathrm{b}$ & se & $\mathrm{b}$ & se & $\mathrm{b}$ & se & $\mathrm{b}$ & se & $\mathrm{b}$ & se \\
\hline Intercept & -1.16 & $.241 * * *$ & -1.15 & $.239 * * *$ & -1.15 & $.241 * * *$ & -.276 & .309 & -.488 & .322 & -.295 & .309 \\
\hline Mainline Protestant & -0.56 & .044 & -.057 & .044 & -.055 & .044 & -.185 & .096 & -.175 & .102 & -.186 & .096 \\
\hline Black Protestant & -.077 & .182 & -.082 & .182 & -.079 & .183 & .177 & .153 & .196 & .159 & .177 & .153 \\
\hline Catholic & -.126 & $.038 * * *$ & -.124 & $.038 * * *$ & -.123 & $.038 * * *$ & -.081 & .077 & -.061 & .081 & -.077 & .077 \\
\hline Other Religion & .039 & .054 & .040 & .054 & .041 & .054 & .047 & .098 & .047 & .108 & .049 & .098 \\
\hline Unaffiliated & 1.127 & 1.48 & 1.128 & 1.49 & 1.12 & 1.48 & .240 & $.096 *$ & .205 & $.098 *$ & .237 & $.095^{*}$ \\
\hline Female & .163 & $.029 * * *$ & .163 & $.029 * * *$ & .172 & $.029 * * *$ & .039 & .054 & .023 & .056 & .024 & .053 \\
\hline Age & .042 & $.008 * * *$ & .041 & $.008 * * *$ & .042 & $.008 * * *$ & .022 & .019 & .034 & .020 & .022 & .019 \\
\hline African American & .265 & $.039 * * *$ & .270 & $.039 * * *$ & .263 & $.039 * * *$ & -.038 & .133 & -.024 & .139 & -.035 & .133 \\
\hline Latinx & -.024 & .048 & -.027 & .047 & -.026 & .048 & .058 & .108 & .078 & .110 & .057 & .109 \\
\hline Asian or Pacific Islander & -.129 & .067 & -.127 & .066 & -.124 & .066 & & & & & & \\
\hline Other Race & .231 & $.082 * *$ & .231 & $.082 * *$ & .231 & $.083 * *$ & -.012 & .152 & .004 & .167 & -.009 & .152 \\
\hline Parent College Degree & -.063 & .038 & -.062 & .038 & -.061 & .038 & .050 & .062 & .042 & .064 & .046 & .062 \\
\hline Parent Attendance & -.083 & $.015 * * *$ & -.083 & $.015 * * *$ & -.084 & $.015 * * *$ & -.016 & .014 & -.019 & .015 & -.015 & .014 \\
\hline Parent Married & -.003 & .036 & -.002 & .036 & -.003 & .036 & -.036 & .066 & -.018 & .069 & -.031 & .066 \\
\hline Living in the South & .043 & .030 & .044 & .030 & .044 & .030 & -.051 & .058 & -.072 & .060 & -.048 & .058 \\
\hline Currently in College & -.028 & .036 & -.029 & .036 & -.027 & .036 & -.178 & $.064 * *$ & -.189 & $.067 * *$ & -.178 & $.064 * *$ \\
\hline College Degree & -.124 & $.034 * * *$ & -.124 & $.034 * * *$ & -.125 & $.034 * * *$ & -.024 & .063 & -.038 & .066 & -.023 & .062 \\
\hline Living with Parent & .106 & $.041 * *$ & .103 & $.041 * *$ & .105 & $.041 * *$ & .096 & .072 & .155 & .080 & .098 & .072 \\
\hline Married & .099 & $.032 * *$ & .107 & $.032 * * *$ & .099 & $.032 * *$ & .069 & .067 & .104 & .069 & .069 & .067 \\
\hline Children & .135 & $.033 * * *$ & .145 & $.033 * * *$ & .133 & $.033 * * *$ & .143 & $.068 *$ & .158 & $.070 *$ & .150 & $.068 *$ \\
\hline
\end{tabular}

Notes: See Table 4 for attraction, behavior, and sexual identity results.

$* * * \mathrm{p}<0.001, * * \mathrm{p}<0.01, * \mathrm{p}<0.05$ (two-tailed test) 
Appendix S4. Logistic Regressions of No Religious Affiliation in Wave 1

\begin{tabular}{|c|c|c|c|c|c|c|c|c|c|c|c|c|}
\hline & \multicolumn{6}{|c|}{ National Longitudinal Study of Adolescent to Adult Health } & \multicolumn{6}{|c|}{ National Study of Youth and Religion } \\
\hline & \multicolumn{2}{|c|}{ Model D-1 } & \multicolumn{2}{|c|}{ Model D-2 } & \multicolumn{2}{|c|}{ Model D-3 } & \multicolumn{2}{|c|}{ Model D-4 } & \multicolumn{2}{|c|}{ Model D-5 } & \multicolumn{2}{|c|}{ Model D-6 } \\
\hline & $\mathrm{b}$ & se & $\mathrm{b}$ & se & $\mathrm{b}$ & se & $\mathrm{b}$ & se & $\mathrm{b}$ & se & $\mathrm{b}$ & se \\
\hline \multicolumn{13}{|l|}{ Sexual Attraction (W4) } \\
\hline Same Sex & -.106 & .263 & & & & & & & & & & \\
\hline Same \& Different Sex & .083 & .158 & & & & & & & & & & \\
\hline None & -1.23 & $.547 *$ & & & & & & & & & & \\
\hline Any Same Sex & & & & & & & .217 & .244 & & & & \\
\hline \multicolumn{13}{|l|}{ Sexual Behavior (W4) } \\
\hline Same Sex & & & -.474 & .439 & & & & & & & & \\
\hline Same \& Different Sex & & & .356 & $.119 * *$ & & & & & & & & \\
\hline None & & & -.445 & .495 & & & & & & & & \\
\hline Any Same Sex & & & & & & & & & .190 & .323 & & \\
\hline \multicolumn{13}{|l|}{ Sexual Identity (W4) } \\
\hline Bisexual & & & & & .243 & $.113^{*}$ & & & & & & \\
\hline Gay or Lesbian & & & & & -.089 & .249 & & & & & & \\
\hline Any Sexual Minority & & & & & & & & & & & .318 & .313 \\
\hline $\mathrm{N}$ & \multicolumn{2}{|c|}{13724} & \multicolumn{2}{|c|}{13724} & \multicolumn{2}{|c|}{13724} & \multicolumn{2}{|c|}{1862} & \multicolumn{2}{|c|}{1719} & \multicolumn{2}{|c|}{1862} \\
\hline
\end{tabular}

Notes: All models control for sex, age, race, region, parent service attendance, parent education, and parent marital status.

$* * * \mathrm{p}<0.001, * * \mathrm{p}<0.01, * \mathrm{p}<0.05$ (two-tailed test) 
Appendix S5. OLS Regression of Frequency of Religious Service Attendance in Wave 1

\begin{tabular}{|c|c|c|c|c|c|c|c|c|c|c|c|c|}
\hline & \multicolumn{6}{|c|}{ National Longitudinal Study of Adolescent to Adult Health } & \multicolumn{6}{|c|}{ National Study of Youth and Religion } \\
\hline & \multicolumn{2}{|c|}{ Model E-1 } & \multicolumn{2}{|c|}{ Model E-2 } & \multicolumn{2}{|c|}{ Model E-3 } & \multicolumn{2}{|c|}{ Model E-4 } & \multicolumn{2}{|c|}{ Model E-5 } & \multicolumn{2}{|c|}{ Model E-6 } \\
\hline & $\mathrm{b}$ & se & $\mathrm{b}$ & se & $\mathrm{b}$ & se & $\mathrm{b}$ & se & $\mathrm{b}$ & se & $\mathrm{b}$ & se \\
\hline \multicolumn{13}{|l|}{ Sexual Attraction (W4) } \\
\hline Same Sex & -.325 & $.107 * *$ & & & & & & & & & & \\
\hline Same \& Different Sex & -.204 & $.072 * *$ & & & & & & & & & & \\
\hline None & .148 & .176 & & & & & & & & & & \\
\hline Any Same Sex & & & & & & & -.053 & .050 & & & & \\
\hline \multicolumn{13}{|l|}{ Sexual Behavior (W4) } \\
\hline Same Sex & & & -.187 & .127 & & & & & & & & \\
\hline Same \& Different Sex & & & -.208 & $.051 * * *$ & & & & & & & & \\
\hline None & & & .285 & $.106 * *$ & & & & & & & & \\
\hline Any Same Sex & & & & & & & & & -.030 & .060 & & \\
\hline \multicolumn{13}{|l|}{ Sexual Identity (W4) } \\
\hline Bisexual & & & & & -.263 & $.046 * * *$ & & & & & & \\
\hline Gay or Lesbian & & & & & -.371 & $.090 * * *$ & & & & & & \\
\hline Any Sexual Minority & & & & & & & & & & & -.012 & .060 \\
\hline $\mathrm{N}$ & \multicolumn{2}{|c|}{12066} & \multicolumn{2}{|c|}{12066} & \multicolumn{2}{|c|}{12066} & \multicolumn{2}{|c|}{2059} & \multicolumn{2}{|c|}{1908} & \multicolumn{2}{|c|}{2059} \\
\hline
\end{tabular}

Notes: All models control for religious affiliation, sex, age, race, region, parent service attendance, parent education, and parent marital status.

*** $\mathrm{p}<0.001, * * \mathrm{p}<0.01, * \mathrm{p}<0.05$ (two-tailed test) 
Appendix S6. OLS Regression of Frequency of Prayer in Wave 1

\begin{tabular}{|c|c|c|c|c|c|c|c|c|c|c|c|c|}
\hline & \multicolumn{6}{|c|}{ National Longitudinal Study of Adolescent to Adult Health } & \multicolumn{6}{|c|}{ National Study of Youth and Religion } \\
\hline & \multicolumn{2}{|c|}{ Model F-1 } & \multicolumn{2}{|c|}{ Model F-2 } & \multicolumn{2}{|c|}{ Model F-3 } & \multicolumn{2}{|c|}{ Model F-4 } & \multicolumn{2}{|c|}{ Model F-5 } & \multicolumn{2}{|c|}{ Model F-6 } \\
\hline & $\mathrm{b}$ & se & $\mathrm{b}$ & se & $\mathrm{b}$ & se & $\mathrm{b}$ & se & $\mathrm{b}$ & se & $\mathrm{b}$ & se \\
\hline \multicolumn{13}{|l|}{ Sexual Attraction (W4) } \\
\hline Same Sex & -.180 & .102 & & & & & & & & & & \\
\hline Same \& Different Sex & -.088 & .074 & & & & & & & & & & \\
\hline None & .135 & .159 & & & & & & & & & & \\
\hline Any Same Sex & & & & & & & -.018 & .065 & & & & \\
\hline \multicolumn{13}{|l|}{ Sexual Behavior (W4) } \\
\hline Same Sex & & & .092 & .133 & & & & & & & & \\
\hline Same \& Different Sex & & & -.037 & .053 & & & & & & & & \\
\hline None & & & .041 & .107 & & & & & & & & \\
\hline Any Same Sex & & & & & & & & & -.020 & .072 & & \\
\hline \multicolumn{13}{|l|}{ Sexual Identity (W4) } \\
\hline Bisexual & & & & & -.103 & $.048^{*}$ & & & & & & \\
\hline Gay or Lesbian & & & & & -.242 & $.097 * *$ & & & & & & \\
\hline Any Sexual Minority & & & & & & & & & & & .060 & .079 \\
\hline $\mathrm{N}$ & \multicolumn{2}{|c|}{12056} & \multicolumn{2}{|c|}{12056} & \multicolumn{2}{|c|}{12056} & \multicolumn{2}{|c|}{2054} & \multicolumn{2}{|c|}{1906} & \multicolumn{2}{|c|}{2054} \\
\hline
\end{tabular}

Notes: All models control for religious affiliation, sex, age, race, region, parent service attendance, parent education, and parent marital status.

*** $\mathrm{p}<0.001, * * \mathrm{p}<0.01, * \mathrm{p}<0.05$ (two-tailed test) 